\title{
Urinary incontinence in physically active women
}

\author{
Katarzyna Olga Szczepańska ${ }^{1}$, Tomasz Chomiuk $^{2}$, Andrzej Permoda ${ }^{3}$ \\ ${ }^{1}$ Faculty of Medicine, Medical University of Warsaw, Poland \\ 23rd Department of Internal Medicine and Cardiology, Medical University of Warsaw, Poland \\ ${ }^{3}$ Department of Kinesiology, Gdańsk University of Physical Education and Sport, Gdańsk, Poland
}

Correspondence to: Katarzyna Olga Szczepańska, email: katarzyna_szczepanska6@wp.pl

DOI: https://doi.org/10.5114/phr.2021.111808

Received: 13.09.2021 Reviewed: 18.10.2021 Accepted: 19.10.2021

\begin{abstract}
Background: The problem of urinary incontinence (UI) is present in the sports community, and women in this group are more likely to experience it compared to those who are physically inactive.
\end{abstract}

Aims: This study aimed to determine the extent of urinary incontinence among physically active women and to indicate the influence of participants' sociodemographic characteristics and variables describing their physical activity on the level of this problem. An additional objective was to assess subjects' awareness of the prevention and treatment methods of urinary incontinence and check whether they use them to protect and treat this dysfunction.

Material and methods: The data was obtained from 736 women. The research used the method of a diagnostic survey, the technique of an Internet questionnaire for which the proprietary interview questionnaire was used. The obtained results were statistically analyzed using statistical measures and tests.

Results: Urinary incontinence was reported by $18.2 \%$ of the participants. A statistically significant association between age, history of childbirth, education, and prevalence of urinary incontinence was found. There was no statistically significant relationship between training duration, number of systematic workouts per week, length and intensity of a single workout and urinary incontinence.

Conclusion: The problem of urinary incontinence is present in the sports community, but further research should be conducted to analyze the prevalence of this issue in this population.
Key words

risk factors, physical activity, incontinence, urinary incontinence. 


\section{Introduction}

Urinary incontinence (UI) is one of the most prevalent medical and psychological problems in modern society, which primarily affects women, regardless of their age [1,2]. As a result, increased emphasis is being placed on the pelvic floor muscles and their impact on women's health [3].

However, it is still an embarrassing and neglected problem for many women. Any action is usually taken only when the problem becomes large enough to interfere with or even dictate the terms of daily life. This is compounded by serious secondary somatic and psychological complications. UI symptoms cause social isolation, withdrawal from social life, hinder efficient functioning and often force lifestyle changes [4-6].

Physical activity has many benefits, including improving the efficiency of the body, preventing many diseases, increasing muscle strength and endurance, and by increasing the level of endorphins in the body has a positive effect on our mood. However, exhausting, intensive workouts, especially those accompanied by a lot of running and jumping, negatively affect the pelvic floor, which may eventually lead to urinary incontinence $[7,8]$.

\section{Aims}

The study aimed to determine the prevalence of urinary incontinence among women undertaking systematic physical activity and to indicate the influence of individual sociodemographic characteristics and variables describing their physical activity on the level of this problem. The following research questions were posed in both areas identified:

- Do forms of physical activity have an impact on the occurrence of urinary incontinence?

- Does the length of training, the number of regular training sessions per week, the length of a single training session in minutes and the intensity of the training have any influence on the occurrence of urinary incontinence?
- Does age, childbirth, bodyweight expressed by objectified BMI, and participants' level of education affect the prevalence of urinary incontinence?

An additional aim was to assess the subjects' awareness of prevention and treatment of urinary incontinence and to see if the women were using these strategies to protect and treat this pelvic floor dysfunction.

\section{Material and methods}

Data for the study was obtained between February and March 2020 from women undertaking regular physical activity at different levels.

A group of 736 women between 16 and 64 years old (average age was 28.8 years old) took part in this study. The respondents were mostly young women - nulliparous, up to 28 years old, with normal BMI and higher education. The studied group was diversified in terms of physical activity, and the most numerous group $(1 / 3)$ were runners and women undertaking endurance activities. Moreover, over half of the participants were women with long training history who had been physically active for three years or longer. Detailed characteristics of the participants are outlined in Table 1 and Table 2.

The study was carried out using the diagnostic survey method, utilizing the online survey technique through a custom survey questionnaire prepared in Google Form, obtaining 736 responses. The research tool was posted on groups related to different forms of physical activity on one of the social media platforms. All participants were informed of the objectives and principles of the study, and the survey was voluntary and anonymous.

The customized online questionnaire consisted of 23 questions. The sociodemographic data included age, height, weight, history of childbirth, and education. In addition, the questionnaire included questions about the type of physical ac- 
Table 1. Sociodemographic characteristics of the respondents.

\begin{tabular}{|c|c|c|}
\hline Feature & $\mathbf{n}$ & $\%$ \\
\hline \multicolumn{3}{|l|}{ Age } \\
\hline up to 28 years & 394 & 53.5 \\
\hline 29-40 years & 243 & 33.0 \\
\hline 41 years and older & 99 & 13.5 \\
\hline \multicolumn{3}{|l|}{ Labour } \\
\hline yes & 229 & 31.1 \\
\hline no & 507 & 68.9 \\
\hline \multicolumn{3}{|l|}{ Bodyweight } \\
\hline underweight & 72 & 9.8 \\
\hline norm & 564 & 76.7 \\
\hline overweight & 100 & 13.6 \\
\hline \multicolumn{3}{|l|}{ Education } \\
\hline primary & 81 & 11.0 \\
\hline secondary & 239 & 32.5 \\
\hline higher & 416 & 56.5 \\
\hline
\end{tabular}

Table 2. Characteristics of respondents on physical activity variables.

\begin{tabular}{|l|c|c|}
\hline Feature & $\mathbf{n}$ & $\%$ \\
\hline Forms of physical activity undertaken & 268 & 36.4 \\
\hline running and endurance sports & 96 & 13.0 \\
\hline gym & 100 & 13.6 \\
\hline CrossFit and strength training & 114 & 15.5 \\
\hline fitness & 107 & 14.5 \\
\hline sports games & 51 & 6.9 \\
\hline dancing & & \\
\hline
\end{tabular}




\begin{tabular}{|l|c|c|}
\hline Training experience & 92 & 12.5 \\
\hline up to 1 year & 224 & 30.4 \\
\hline 1 to 3 years & 420 & 57.1 \\
\hline 3 years and longer & \multicolumn{2}{|c|}{} \\
\hline Number of trainings per week & 137 & 18.6 \\
\hline 2 & 262 & 35.6 \\
\hline 3 & 337 & 45.8 \\
\hline $4-7$ & \multicolumn{2}{|c|}{} \\
\hline Duration of a single training session & 55 & 7.5 \\
\hline 30 min & 544 & 73.9 \\
\hline $1-1.5 \mathrm{~h}$ & 137 & 18.6 \\
\hline 2 hours and more & & \\
\hline Training intensity & 154 & 20.9 \\
\hline low & 231 & 31.4 \\
\hline medium & 351 & 47.7 \\
\hline high & \multicolumn{2}{|c|}{} \\
\hline
\end{tabular}

tivity performed, training experience, number of training sessions per week, length of a single training session, and questions designed to assess the occurrence of UI episodes, their circumstances and frequency. The tool also consisted of questions about the knowledge and use of prevention methods of urinary incontinence, the opinion of the participants on the design of educational and informational programs, the forms of treatment chosen for this problem and the evaluation of the effects after the use of these methods. The last question was designed to explore the impact of this problem on the aspects of a woman's life. The questions were either closed or open-ended and allowed choosing one or more answers from the listed options and providing their answer.
The obtained research results were statistically analyzed by calculating the frequencies and percentage distributions of answers to each question in the questionnaire. To answer the research questions, percentage profile analysis was used in contingency (cross) tables by placing the independent variables in their rows and the dependent variables in their columns. To assess the significance of the distributions in the table cells, the Pearson's Chi-square test of independence was calculated. Cramer's V coefficient, taking values from zero to one, was used to test the strength of the relationship between the investigated factors. The assumed significance level was $\alpha \geq 0.05$. 


\section{Results}

Results of studies on urinary incontinence and correlations between examined variables. The analysis of the responses provided by participants shows that among the physically active women, $18.2 \%$ reported occurrence of the problem, $8 \%$ reported the presence of the problem in the past, and the remaining $73.8 \%$ of the women reported the absence of this issue.

Among women who have had a problem with urinary incontinence in the past, a significant proportion (81.3\%) reported experiencing episodes of UI during training. Situations in which abdominal press was activated (laughing, coughing, sneezing) were the triggering factor for incontinence in $52.3 \%$ of women, while in $15.5 \%$ of respondents, it occurred during lifting. Very few women indicated that uncontrollable urine discharge occurred during activities such as getting out of bed, walking, or lying down (Figure 1).

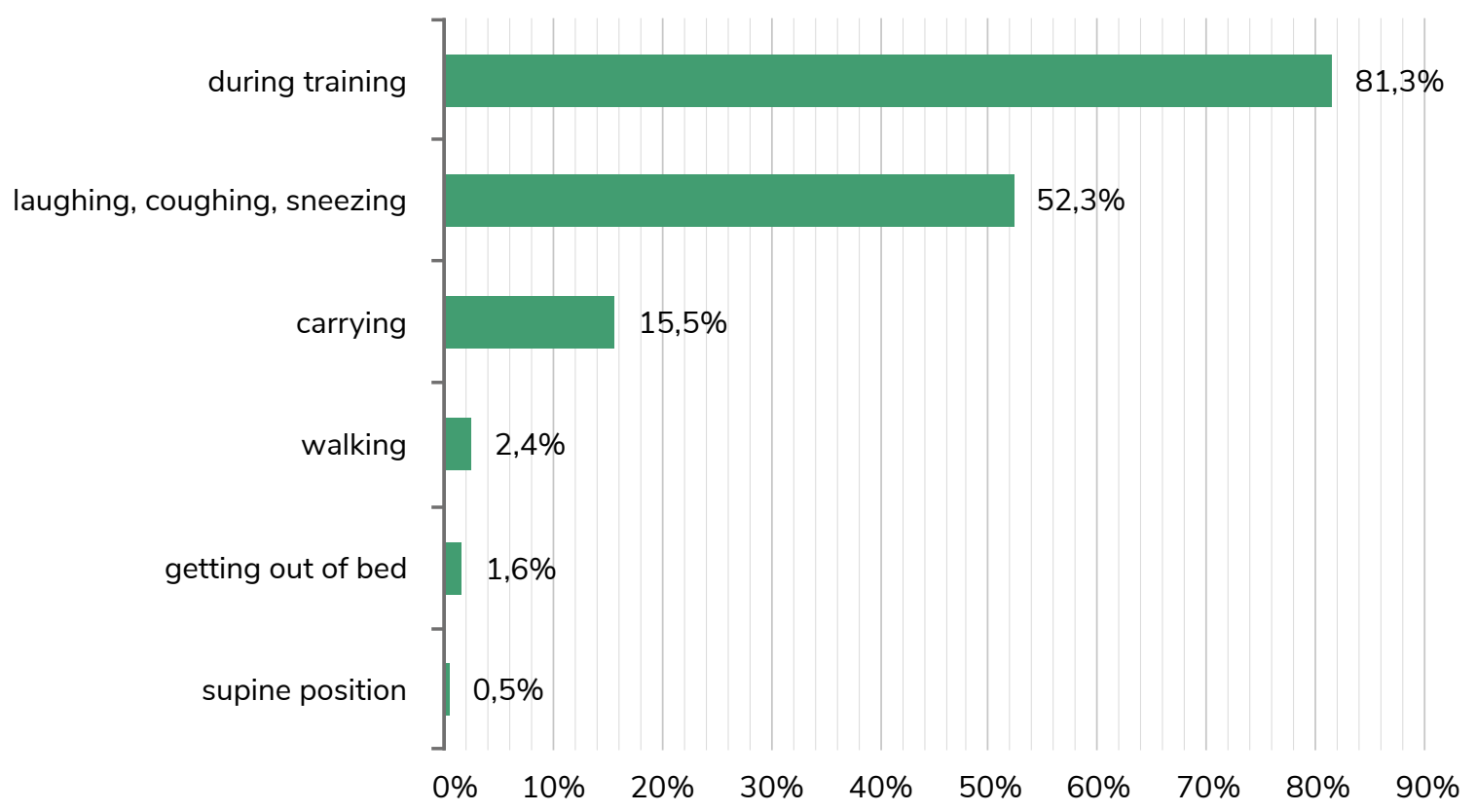

Figure 1. Circumstances in which urine leakage occurs.

${ }^{*}$ Respondents could give more than one answer.

Although the majority of women reported urine incontinence during exercise, the vast majority (over 81.9\%) said that it did not affect their physical activity, $17.1 \%$ reduced the activity and only $1 \%$ completely stopped it.

The frequency of UI varied among women who confirmed the symptoms of uncontrollable urine discharge. $53.4 \%$ of women reported occasional episodes of urine incontinence, $21.8 \%$ several times a week, and $21.2 \%$ several times a month. Some participants (3.6\%) complained about daily UI. 


\section{Type of physical activity and urinary incontinence}

The data distributions in table 3 indicate that the forms of exercise most likely to induce UI are CrossFit and activities that combine strength and endurance exercises. The second most likely physical activity to put women at risk of developing UI are running and endurance activities. The per- centages of women experiencing it are lower for the other activities. The data in the table indicate that, outside of CrossFit, the vast majority of women who engage in regular physical activity do not experience this problem. The form of activity in which UI is observed in only one-tenth of the respondents is dancing (Table 3).

Table 3. Incidence of urinary incontinence in relation to the type of physical activity.

\begin{tabular}{|c|c|c|c|c|c|c|c|}
\hline \multirow{2}{*}{$\begin{array}{l}\text { Type of physical } \\
\text { activity }\end{array}$} & \multicolumn{3}{|c|}{ Urinary incontinence } & \multirow{2}{*}{ Overall } & \multirow{2}{*}{$\begin{array}{l}\text { Pearson's } \\
\text { Chi2 }\end{array}$} & \multirow{2}{*}{$\begin{array}{c}\text { Cramér's } \\
\text { V }\end{array}$} & \multirow{2}{*}{$\begin{array}{c}\text { p- } \\
\text { Value }\end{array}$} \\
\hline & Occurs & $\begin{array}{c}\text { Does not } \\
\text { occur }\end{array}$ & $\begin{array}{l}\text { Occurred and } \\
\text { does not occur }\end{array}$ & & & & \\
\hline \multirow{2}{*}{$\begin{array}{l}\text { running and } \\
\text { endurance }\end{array}$} & 55 & 194 & 19 & 268 & \multirow[t]{14}{*}{28.3} & \multirow[t]{14}{*}{0.14} & \multirow[t]{14}{*}{0.002} \\
\hline & $20.5 \%$ & $72.4 \%$ & $7.1 \%$ & $36.4 \%$ & & & \\
\hline \multirow{2}{*}{ gym workout } & 14 & 71 & 11 & 96 & & & \\
\hline & $14.6 \%$ & $74.0 \%$ & $11.5 \%$ & $13.0 \%$ & & & \\
\hline \multirow{2}{*}{$\begin{array}{l}\text { CrossFit and } \\
\text { strength training }\end{array}$} & 29 & 58 & 13 & 100 & & & \\
\hline & $29.0 \%$ & $58.0 \%$ & $13.0 \%$ & $13.6 \%$ & & & \\
\hline \multirow{2}{*}{ fitness forms } & 21 & 85 & 8 & 114 & & & \\
\hline & $18.4 \%$ & $74.6 \%$ & $7.0 \%$ & $15.5 \%$ & & & \\
\hline \multirow{2}{*}{ sports games } & 10 & 93 & 4 & 107 & & & \\
\hline & $9.3 \%$ & $86.9 \%$ & $3.7 \%$ & $14.5 \%$ & & & \\
\hline \multirow{2}{*}{ dance } & 5 & 42 & 4 & 51 & & & \\
\hline & $9.8 \%$ & $82.4 \%$ & $7.8 \%$ & $6.9 \%$ & & & \\
\hline \multirow{2}{*}{ total } & 134 & 543 & 59 & 736 & & & \\
\hline & $18.2 \%$ & $73.8 \%$ & $8.0 \%$ & $100.0 \%$ & & & \\
\hline
\end{tabular}

Training experience, number of trainings per week, length of a single training session and its intensity, and urinary incontinence

The study showed that the longer training experience, the number of training sessions, the longer duration of a single training session and its intensity did not significantly correlate with a higher prevalence of urinary incontinence. To assess the effects of training intensity on urinary incontinence, a weekly training intensity indicator was created from the variable number of training sessions per week and the training duration in minutes, being the ratio of the indicated variables. The women were then divided into three groups according to the number of minutes they trained per week: low intensity (when they trained up to 150 minutes), medium intensity (when they trained between 240 and 360 minutes) and 
high intensity (when they trained seven or more hours per week). The data distributions in tables 4-7 are random and do not contribute significantly to the discussed problem. Although the data in Table 5 do not show statistical significance, analysis of the percentage profiles indicates that the proportion of women with urinary inconti- nence is lower in the group of women who engage in physical activity twice a week compared with women who engage in physical activity at frequencies of 3 and $4-7$ times a week. Furthermore, UI is slightly more common in those who train for shorter periods (30 min - 1.5h) than those who train for $2 \mathrm{~h}$ and longer (Tables 4-7).

Table 4. Incidence of urinary incontinence in relation to the training experience.

\begin{tabular}{|c|c|c|c|c|c|c|c|}
\hline \multirow{2}{*}{$\begin{array}{l}\text { Training } \\
\text { experience }\end{array}$} & \multicolumn{3}{|c|}{ Urinary incontinence } & \multirow{2}{*}{ Overall } & \multirow{2}{*}{$\begin{array}{l}\text { Pearson's } \\
\text { Chi2 }\end{array}$} & \multirow{2}{*}{$\begin{array}{c}\text { Cramér's } \\
\text { V }\end{array}$} & \multirow{2}{*}{$\begin{array}{c}\text { p- } \\
\text { Value }\end{array}$} \\
\hline & Occurs & $\begin{array}{l}\text { Does not } \\
\text { occur }\end{array}$ & $\begin{array}{l}\text { Occurred and } \\
\text { does not occur }\end{array}$ & & & & \\
\hline up to 1 year & $\begin{array}{l}17 \\
18.5 \%\end{array}$ & $\begin{array}{l}69 \\
75.0 \%\end{array}$ & $\begin{array}{l}6 \\
6.5 \%\end{array}$ & $\begin{array}{l}92 \\
12.5 \%\end{array}$ & \multirow[t]{4}{*}{4.18} & \multirow[t]{4}{*}{0.05} & \multirow[t]{4}{*}{0.382} \\
\hline one to 3 years & $\begin{array}{l}35 \\
15.6 \%\end{array}$ & $\begin{array}{l}165 \\
73.7 \%\end{array}$ & $\begin{array}{l}24 \\
10.7 \%\end{array}$ & $\begin{array}{l}224 \\
30.4 \%\end{array}$ & & & \\
\hline $\begin{array}{l}3 \text { years and } \\
\text { longer }\end{array}$ & $\begin{array}{l}82 \\
19.5 \%\end{array}$ & $\begin{array}{l}309 \\
73.6 \%\end{array}$ & $\begin{array}{l}29 \\
6.9 \%\end{array}$ & $\begin{array}{l}420 \\
57.1 \%\end{array}$ & & & \\
\hline total & $\begin{array}{l}134 \\
18.2 \%\end{array}$ & $\begin{array}{l}543 \\
73.8 \%\end{array}$ & $\begin{array}{l}59 \\
8.0 \%\end{array}$ & $\begin{array}{l}736 \\
100.0 \%\end{array}$ & & & \\
\hline
\end{tabular}

Table 5. Incidence of urinary incontinence in relation to the number of systematic training per week.

\begin{tabular}{|c|c|c|c|c|c|c|c|}
\hline \multirow{2}{*}{$\begin{array}{l}\text { Number } \\
\text { of trainings } \\
\text { per week }\end{array}$} & \multicolumn{3}{|c|}{ Urinary incontinence } & \multirow{2}{*}{ Overall } & \multirow{2}{*}{$\begin{array}{l}\text { Pearson's } \\
\text { Chi2 }\end{array}$} & \multirow{2}{*}{$\begin{array}{c}\text { Cramér's } \\
\text { V }\end{array}$} & \multirow{2}{*}{$\begin{array}{c}\text { p- } \\
\text { Value }\end{array}$} \\
\hline & Occurs & $\begin{array}{l}\text { Does not } \\
\text { occur }\end{array}$ & $\begin{array}{l}\text { Occurred and } \\
\text { does not occur }\end{array}$ & & & & \\
\hline \multirow{2}{*}{2} & 19 & 112 & 6 & 137 & \multirow[t]{8}{*}{7.58} & \multirow[t]{8}{*}{0.07} & \multirow[t]{8}{*}{0.108} \\
\hline & $13.9 \%$ & $81.8 \%$ & $4.4 \%$ & $18.6 \%$ & & & \\
\hline \multirow{2}{*}{3} & 51 & 192 & 19 & 262 & & & \\
\hline & $19.5 \%$ & $73.3 \%$ & $7.3 \%$ & $35.6 \%$ & & & \\
\hline \multirow{2}{*}{$4-7$} & 64 & 239 & 34 & 337 & & & \\
\hline & $19.0 \%$ & $70.9 \%$ & $10.1 \%$ & $45.8 \%$ & & & \\
\hline \multirow{2}{*}{ total } & 134 & 543 & 59 & 736 & & & \\
\hline & $18.2 \%$ & $73.8 \%$ & $8.0 \%$ & $100.0 \%$ & & & \\
\hline
\end{tabular}


Table 6. Incidence of urinary incontinence in relation to the length of a single training session.

\begin{tabular}{|c|c|c|c|c|c|c|c|}
\hline \multirow{2}{*}{$\begin{array}{l}\text { Length of a } \\
\text { single training } \\
\text { session }\end{array}$} & \multicolumn{3}{|c|}{ Urinary incontinence } & \multirow{2}{*}{ Overall } & \multirow{2}{*}{$\begin{array}{l}\text { Pearson's } \\
\text { Chi2 }\end{array}$} & \multirow{2}{*}{$\begin{array}{c}\text { Cramér's } \\
\text { V }\end{array}$} & \multirow{2}{*}{$\begin{array}{c}\text { p- } \\
\text { Value }\end{array}$} \\
\hline & Occurs & $\begin{array}{l}\text { Does not } \\
\text { occur }\end{array}$ & $\begin{array}{l}\text { Occurred and } \\
\text { does not occur }\end{array}$ & & & & \\
\hline \multirow{2}{*}{$0,5 \mathrm{~h}$} & 13 & 37 & 5 & 55 & \multirow[t]{8}{*}{8.55} & \multirow[t]{8}{*}{0.08} & \multirow[t]{8}{*}{0.073} \\
\hline & $23.6 \%$ & $63.7 \%$ & $9.1 \%$ & $7.5 \%$ & & & \\
\hline \multirow{2}{*}{$1-1.5 \mathrm{~h}$} & 106 & 392 & 46 & 544 & & & \\
\hline & $19.5 \%$ & $72.1 \%$ & $8.5 \%$ & $73.9 \%$ & & & \\
\hline \multirow{2}{*}{$2 \mathrm{~h}$ and longer } & 15 & 114 & 8 & 137 & & & \\
\hline & $10.9 \%$ & $83.2 \%$ & $5.8 \%$ & $18.6 \%$ & & & \\
\hline \multirow{2}{*}{ total } & 134 & 543 & 59 & 736 & & & \\
\hline & $18.2 \%$ & $73.8 \%$ & $8.0 \%$ & $100.0 \%$ & & & \\
\hline
\end{tabular}

Table 7. Incidence of urinary incontinence in relation to training intensity.

\begin{tabular}{|c|c|c|c|c|c|c|c|}
\hline \multirow{2}{*}{$\begin{array}{l}\text { Training } \\
\text { intensity }\end{array}$} & \multicolumn{3}{|c|}{ Urinary incontinence } & \multirow{2}{*}{ Overall } & \multirow{2}{*}{$\begin{array}{l}\text { Pearson's } \\
\text { Chi2 }\end{array}$} & \multirow{2}{*}{$\begin{array}{c}\text { Cramér's } \\
\text { V }\end{array}$} & \multirow{2}{*}{$\begin{array}{c}\text { p- } \\
\text { Value }\end{array}$} \\
\hline & Occurs & $\begin{array}{l}\text { Does not } \\
\text { occur }\end{array}$ & $\begin{array}{l}\text { Occurred and } \\
\text { does not occur }\end{array}$ & & & & \\
\hline \multirow{2}{*}{ low } & 27 & 117 & 10 & 154 & \multirow[t]{8}{*}{0.97} & \multirow[t]{8}{*}{0.03} & \multirow[t]{8}{*}{0.914} \\
\hline & $17.5 \%$ & $76.0 \%$ & $6.5 \%$ & $20.9 \%$ & & & \\
\hline \multirow{2}{*}{ medium } & 42 & 171 & 18 & 231 & & & \\
\hline & $18.2 \%$ & $74.0 \%$ & $7.8 \%$ & $31.4 \%$ & & & \\
\hline \multirow{2}{*}{ high } & 65 & 255 & 31 & 351 & & & \\
\hline & $18.5 \%$ & $72.6 \%$ & $8.8 \%$ & $47.7 \%$ & & & \\
\hline \multirow{2}{*}{ total } & 134 & 543 & 59 & 736 & & & \\
\hline & $18.2 \%$ & $73.8 \%$ & $8.0 \%$ & $100.0 \%$ & & & \\
\hline
\end{tabular}

\section{Age and urinary incontinence}

The data distributions in Table 8 demonstrate a significant difference between the group of women under 28 years old and the older group. This problem was more likely to affect women of older ages. The data revealed that this problem was the least common among women under 28 years of age (Table 8).

\section{Childbirth and urinary incontinence}

Statistical analysis revealed a statistically significant relationship between physically active women who gave birth and those who did not and the occurrence of UI. Furthermore, the data indicate that this problem was more common among women who had given birth than those who had not (Table 9). 
Table 8. Incidence of urinary incontinence in relation to age.

\begin{tabular}{|c|c|c|c|c|c|c|c|}
\hline \multirow{2}{*}{ Age } & \multicolumn{3}{|c|}{ Urinary incontinence } & \multirow{2}{*}{ Overall } & \multirow{2}{*}{$\begin{array}{l}\text { Pearson's } \\
\text { Chi2 }\end{array}$} & \multirow{2}{*}{$\begin{array}{c}\text { Cramér's } \\
\text { V }\end{array}$} & \multirow{2}{*}{$\begin{array}{c}\text { p- } \\
\text { Value }\end{array}$} \\
\hline & Occurs & $\begin{array}{c}\text { Does not } \\
\text { occur }\end{array}$ & $\begin{array}{l}\text { Occurred and } \\
\text { does not occur }\end{array}$ & & & & \\
\hline \multirow{2}{*}{ up to 28 years } & 43 & 337 & 24 & 394 & \multirow[t]{8}{*}{43.2} & \multirow[t]{8}{*}{0.17} & \multirow[t]{8}{*}{0.000} \\
\hline & $10.9 \%$ & $83.0 \%$ & $6.1 \%$ & $53.5 \%$ & & & \\
\hline \multirow{2}{*}{ 29-40 years } & 67 & 156 & 20 & 243 & & & \\
\hline & $27.6 \%$ & $64.2 \%$ & $8.2 \%$ & $33.0 \%$ & & & \\
\hline \multirow{2}{*}{41 and older } & 24 & 60 & 15 & 99 & & & \\
\hline & $24.2 \%$ & $60.6 \%$ & $15.2 \%$ & $13.5 \%$ & & & \\
\hline \multirow{2}{*}{ total } & 134 & 543 & 59 & 736 & & & \\
\hline & $18.2 \%$ & $73.8 \%$ & $8.0 \%$ & $100.0 \%$ & & & \\
\hline
\end{tabular}

Table 9. Incidence of urinary incontinence in relation to labour.

\begin{tabular}{|c|c|c|c|c|c|c|c|}
\hline \multirow{2}{*}{ Labour } & \multicolumn{3}{|c|}{ Urinary incontinence } & \multirow{2}{*}{ Overall } & \multirow{2}{*}{$\begin{array}{l}\text { Pearson's } \\
\text { Chi2 }\end{array}$} & \multirow{2}{*}{$\begin{array}{c}\text { Cramér's } \\
\text { V }\end{array}$} & \multirow{2}{*}{$\begin{array}{c}p- \\
\text { Value }\end{array}$} \\
\hline & Occurs & $\begin{array}{c}\text { Does not } \\
\text { occur }\end{array}$ & $\begin{array}{l}\text { Occurred and } \\
\text { does not occur }\end{array}$ & & & & \\
\hline \multirow{2}{*}{ yes } & 73 & 133 & 23 & 229 & \multirow[t]{6}{*}{46.9} & \multirow[t]{6}{*}{0.25} & \multirow[t]{6}{*}{0.000} \\
\hline & $31.9 \%$ & $58.1 \%$ & $10.0 \%$ & $31.1 \%$ & & & \\
\hline \multirow{2}{*}{ no } & 61 & 410 & 36 & 507 & & & \\
\hline & $12.0 \%$ & $80.9 \%$ & $7.1 \%$ & $68.9 \%$ & & & \\
\hline \multirow{2}{*}{ total } & 134 & 543 & 59 & 736 & & & \\
\hline & $18.2 \%$ & $73.8 \%$ & $8.0 \%$ & $100.0 \%$ & & & \\
\hline
\end{tabular}

\section{Bodyweight and urinary incontinence}

It was also examined whether the bodyweight of participants, represented by the objectified BMI index, influenced the severity of urinary incontinence. The data distributions in Table 10 were not statistically significant, but the analysis of the percentage profiles indicates a greater tendency for it to occur in overweight individuals. Conversely, normal weight and underweight subjects had lower women experiencing these issues (Table 10).

\section{Education and urinary incontinence}

Statistical analysis indicates that there is an association between the level of education and UI. The data showed that women with higher education were more likely to report impaired urinary control. The influence of age variable is quite likely to be at play. Considering the fact that the surveyed women were generally young (mean age 28.8 years), the women who declared higher education may have been older (Table 11). 
Table 10. Incidence of urinary incontinence in relation to body weight.

\begin{tabular}{|c|c|c|c|c|c|c|c|}
\hline \multirow{2}{*}{ Bodyweight } & \multicolumn{3}{|c|}{ Urinary incontinence } & \multirow{2}{*}{ Overall } & \multirow{2}{*}{$\begin{array}{l}\text { Pearson's } \\
\text { Chi2 }\end{array}$} & \multirow{2}{*}{$\begin{array}{c}\text { Cramér's } \\
\text { V }\end{array}$} & \multirow{2}{*}{$\begin{array}{c}\text { p- } \\
\text { Value }\end{array}$} \\
\hline & Occurs & $\begin{array}{l}\text { Does not } \\
\text { occur }\end{array}$ & $\begin{array}{l}\text { Occurred and } \\
\text { does not occur }\end{array}$ & & & & \\
\hline \multirow{2}{*}{ underweight } & 10 & 59 & 3 & 72 & \multirow[t]{8}{*}{5.53} & \multirow[t]{8}{*}{0.06} & \multirow[t]{8}{*}{0.478} \\
\hline & $13.9 \%$ & $81.9 \%$ & $4.2 \%$ & $9.8 \%$ & & & \\
\hline \multirow{2}{*}{ normal weight } & 103 & 416 & 45 & 564 & & & \\
\hline & $18.3 \%$ & $73.8 \%$ & $8.0 \%$ & $76.6 \%$ & & & \\
\hline \multirow{2}{*}{ overweight } & 21 & 68 & 11 & 100 & & & \\
\hline & $21.0 \%$ & $68.0 \%$ & $11.0 \%$ & $13.6 \%$ & & & \\
\hline \multirow{2}{*}{ total } & 134 & 543 & 59 & 736 & & & \\
\hline & $18.2 \%$ & $73.8 \%$ & $8.0 \%$ & $100.0 \%$ & & & \\
\hline
\end{tabular}

Table 11. Prevalence of urinary incontinence in relation to educational level.

\begin{tabular}{|c|c|c|c|c|c|c|c|}
\hline \multirow{2}{*}{ Education } & \multicolumn{3}{|c|}{ Urinary incontinence } & \multirow{2}{*}{ Overall } & \multirow{2}{*}{$\begin{array}{l}\text { Pearson's } \\
\text { Chi2 }\end{array}$} & \multirow{2}{*}{$\begin{array}{c}\text { Cramér's } \\
\text { V }\end{array}$} & \multirow{2}{*}{$\begin{array}{c}\text { p- } \\
\text { Value }\end{array}$} \\
\hline & Occurs & $\begin{array}{l}\text { Does not } \\
\text { occur }\end{array}$ & $\begin{array}{l}\text { Occurred and } \\
\text { does not occur }\end{array}$ & & & & \\
\hline \multirow{2}{*}{ primary } & 6 & 70 & 5 & 81 & \multirow[t]{8}{*}{18.82} & \multirow[t]{8}{*}{0.11} & \multirow[t]{8}{*}{0.001} \\
\hline & $7.4 \%$ & $86.4 \%$ & $6.2 \%$ & $11.0 \%$ & & & \\
\hline \multirow{2}{*}{ secondary } & 33 & 190 & 16 & 239 & & & \\
\hline & $13.8 \%$ & $79.5 \%$ & $6.7 \%$ & $32.5 \%$ & & & \\
\hline \multirow{2}{*}{ higher } & 95 & 283 & 38 & 416 & & & \\
\hline & $22.8 \%$ & $68.0 \%$ & $9.1 \%$ & $56.5 \%$ & & & \\
\hline \multirow{2}{*}{ total } & 134 & 543 & 59 & 736 & & & \\
\hline & $18.2 \%$ & $73.8 \%$ & $8.0 \%$ & $100.0 \%$ & & & \\
\hline
\end{tabular}

Outcomes on the prevention and treatment of urinary incontinence

The first question regarding prevention was whether, in their opinion, it is important among physically active women. The majority of respondents felt that it was definitely important, important and rather important. Only a small percentage of them indicated that it was rather unimportant, unimportant, and definitely unimportant (Figure 2).
Another question, in which respondents could give more than one answer, referred to the knowledge of prevention methods for the examined issue. Among the preventive factors for urinary incontinence, women most often selected systematic pelvic floor muscle exercises (70.1\%) and treatment of urinary tract infections (58.4\%). At the same time, a healthy lifestyle was declared by $46.3 \%$ and frequent check-ups with the doctor by $20.4 \%$. Only $6.5 \%$ of the respondents indicated 
avoidance of excessive physical activity, while as many as $17.8 \%$ did not know any prevention methods used for urinary incontinence.

In the studied group, as many as $42.8 \%$ of women do not use preventive measures against urinary incontinence due to lack of information on this subject, $34.4 \%$ use it sometimes, $15.2 \%$ do not use preventive measures despite their knowledge, and only $7.6 \%$ of women use it regularly.

Women's opinions on creating informative and educational programs were also explored. Figure 3 indicates that a significant proportion of women are in favour of their creation in women's clinics, in hospitals, in schools, by coaches (Figure 3).

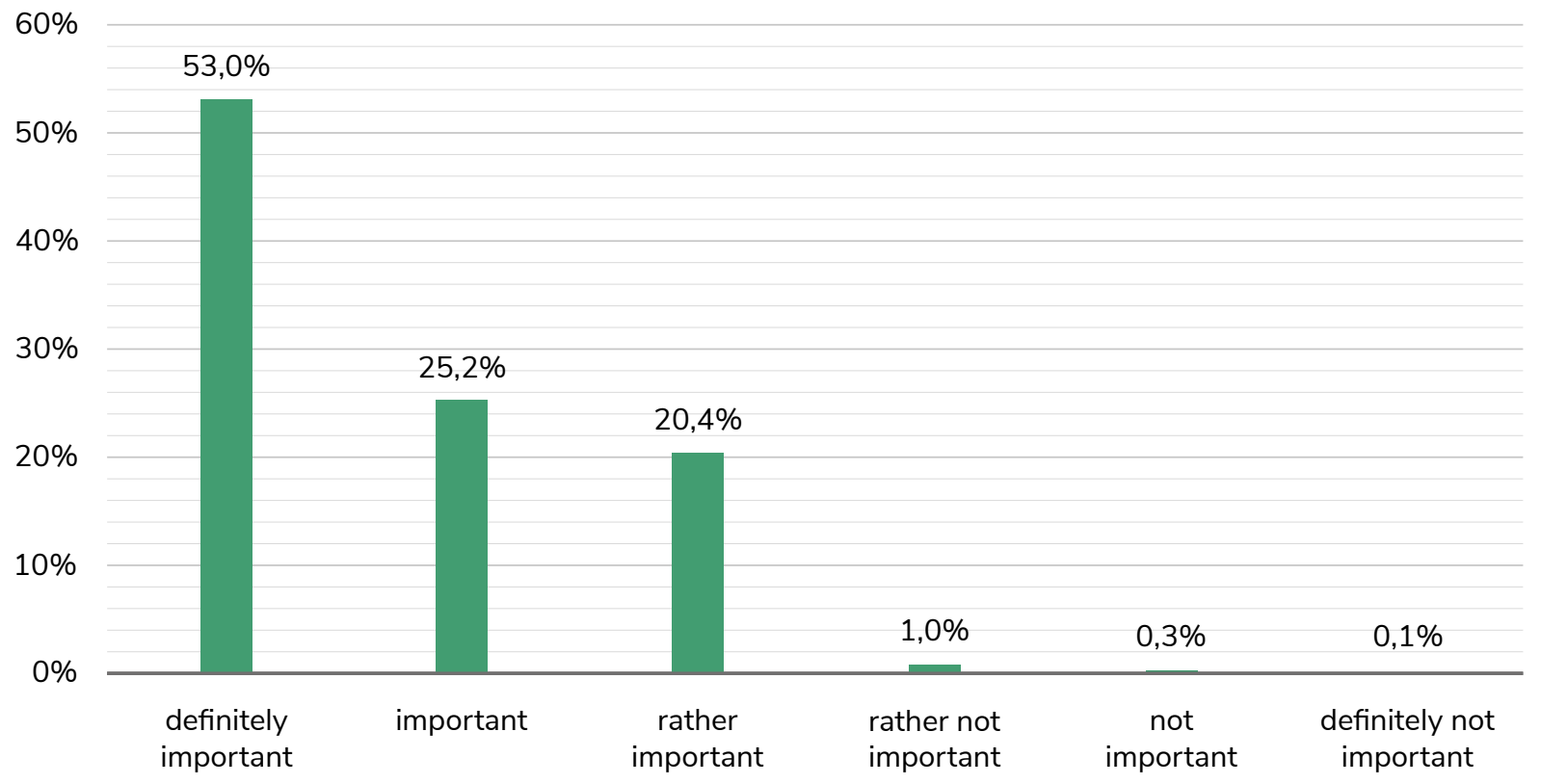

Figure 2. Respondents' opinions on the use of incontinence preventative care.

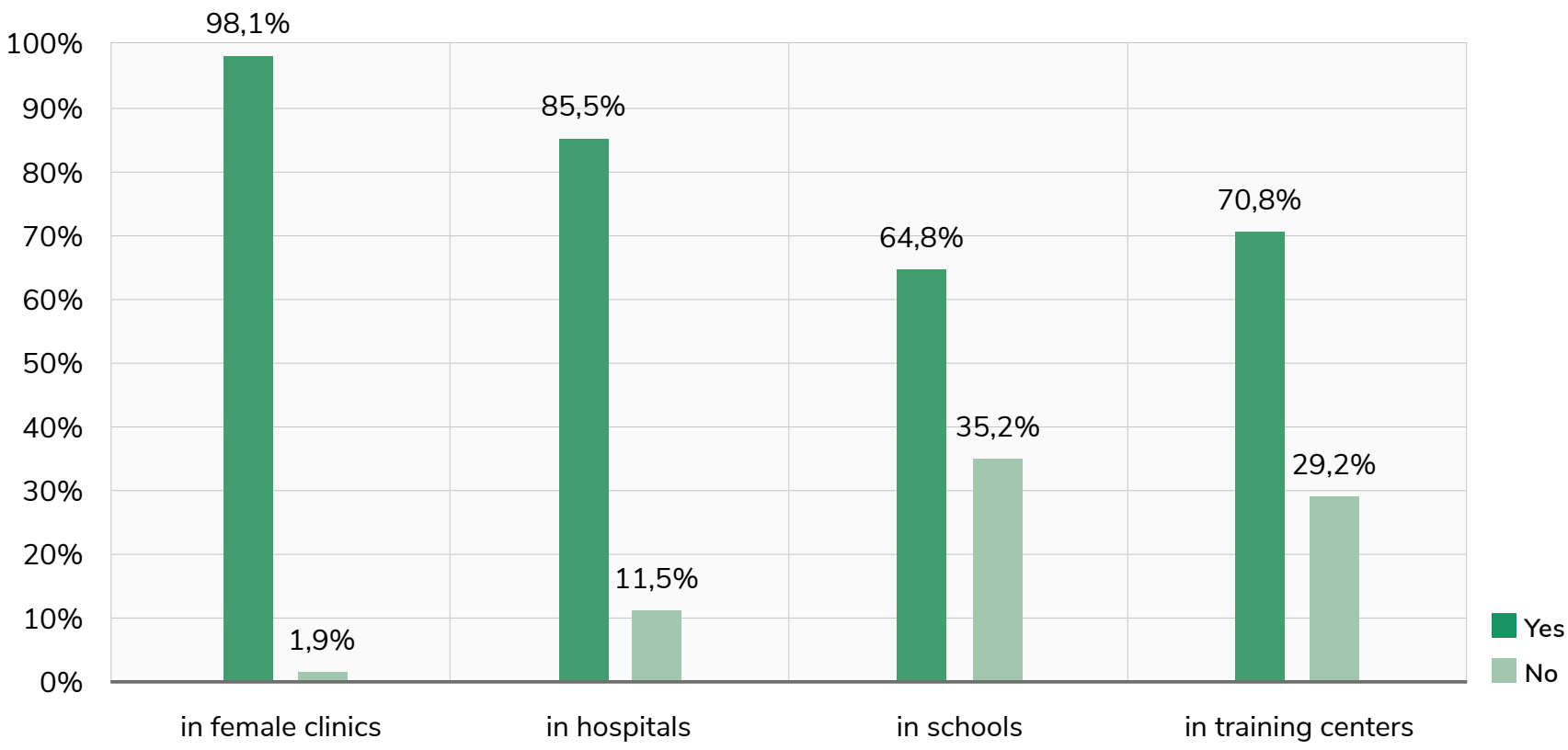

Figure 3. Respondents' opinions on creating information and education programs in a particular setting. 
The next question related to the choice of a specialist for UI problem. Most participants chose a gynaecologist (39.5\%), not much less a general practitioner (33.7\%), followed by a urologist (11.7\%), a physiotherapist (6.9\%), and $0.6 \%$ of women felt that a nephrologist should be contacted. Surprisingly, $7.6 \%$ of respondents do not know whom a woman struggling with this problem should see.

As many as $69.4 \%$ of women admitted that they did not report their problem to anyone and did not seek help, and only $17.1 \%$ of respondents received treatment for this problem. In the questionnaire on the use of UI treatment methods among 17.1\% of women who underwent treatment, the follo- wing results were obtained: most respondents - 72.7\% indicated treatment with pelvic floor muscle exercises, $27.3 \%$ reported pharmacotherapy and $15.2 \%$ biofeedback exercises. Surgeries, vaginal cones, functional electrical stimulation, vibration training, and magnetic stimulation were the least used treatments for this issue (Figure 4). When asked about the effects of the therapy used, women mostly provided positive feedback. As many as $42.5 \%$ reported a significant reduction of the problem, while $33.3 \%$ of women reported no urine flow after treatment. On the other hand, $12.1 \%$ noticed a slight improvement, and the same number of women did not notice any effect of the applied methods.

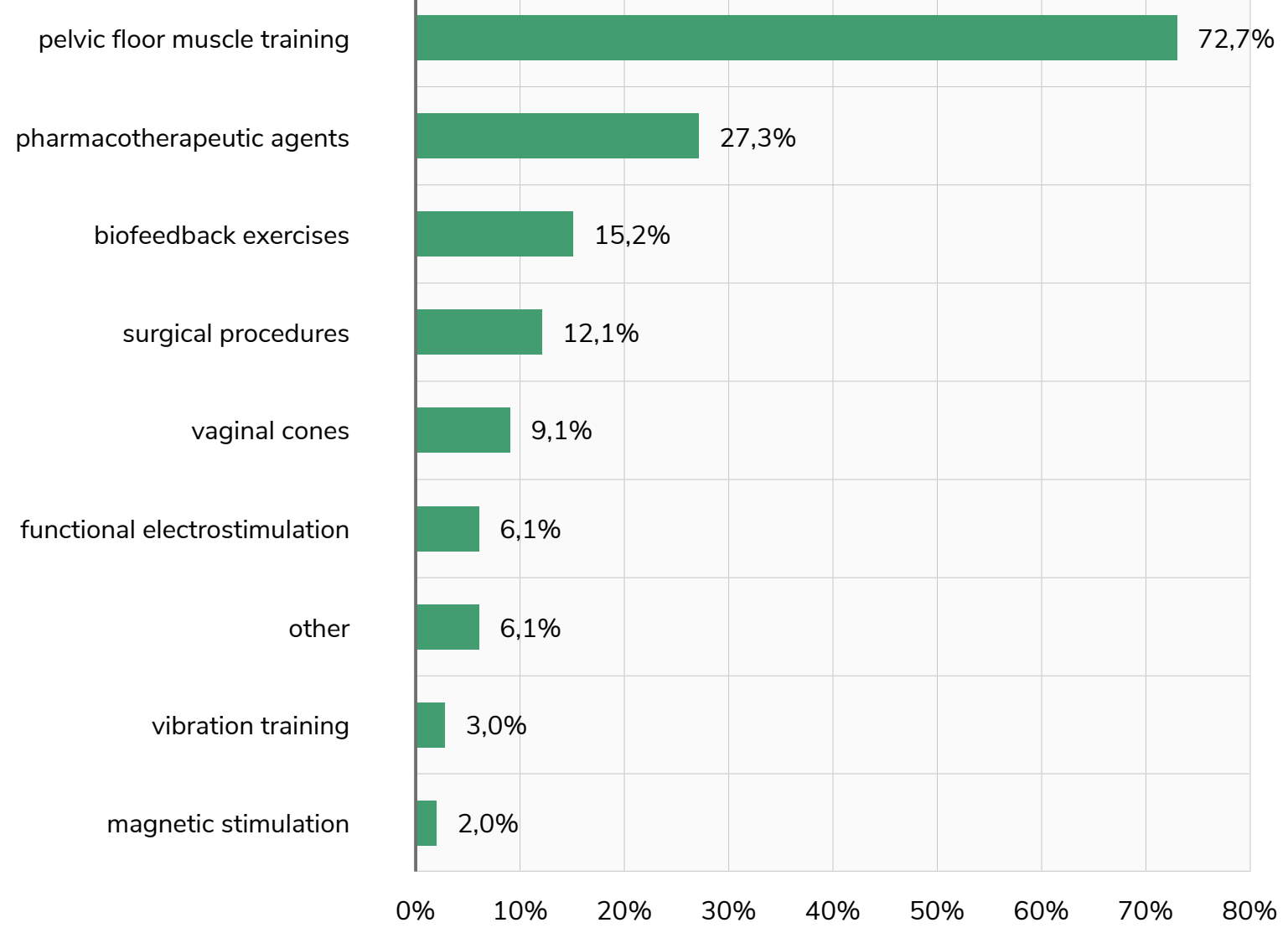

Figure 4. Methods used in the management of urinary incontinence.

${ }^{*}$ Respondents could give more than one answer. 


\section{Discussion}

Although not a life-threatening condition, urinary incontinence in women is considered one of the most serious health problems in modern times because of its prevalence, according to the World Health Organization (WHO) $[10,11]$. There is a lot of research on the effects of physical activity on the pelvic floor and the occurrence of UI. Therefore, it was decided to study this group of women, given that more of them are now engaging in physical activity than ever before [12]. However, Bø et al. [12] describe two possible and opposing hypotheses regarding the effects of physical activity on the pelvic floor:

- Physical activity strengthens the pelvic floor. During general physical activity, pelvic floor muscle co-contraction may occur (indirect effect). This can reduce the area of the levator ani hiatus, causing it to overgrow and shorten, thereby elevating the pelvic floor and internal organs. Theoretically, such morphological changes can reduce the risk of urinary incontinence, faecal incontinence, and lowering of the reproductive organs. On the other hand, it is also possible that these changes may negatively affect labour by making it more difficult for the fetus to go down during pushing.

- In the form of training, general physical activity overloads, stretches, and weakens the pelvic floor. In addition, physical activity increases intra-abdominal pressure, and if the pelvic floor muscles cannot co-contract quickly or strongly enough to counteract this increased pressure or withstand ground reaction forces, the levator ani hiatus may widen, stretch, and weaken the muscles. According to this theory, pelvic floor muscle strain may increase the risk of urinary incontinence, faecal incontinence, and lowering of the reproductive organs, but on the other hand, it should also result in easier childbirth.

The hypothesis that vigorous exercise may be a risk factor for pelvic floor dysfunction, although still small, has more support than the one propo- sing that regular exercise is beneficial for pelvic floor muscle function. Athletes with an optimally functioning pelvic floor are likely to show both positive and negative responses from the pelvic floor to loading; for instance, the pelvic floor of a gymnast can withstand the forces generated when landing on an exercise mat, but not necessarily when landing on a bar. Personal predisposition and the type of physical activity performed can also make a big difference.

The purpose of this article and literature review was to examine how physical activity and type of physical activity may contribute to pelvic floor dysfunction with consideration of other risk factors such as age, BMI, and childbirth. Most of the studies included in the following discussion, aimed at determining the prevalence of urinary incontinence among women with different physical activity levels, were cross-sectional, survey-based, and used validated questionnaires to assess uncontrollable urine discharge and measure physical activity intensity. Various studies have found that incontinence was higher among women who engaged in significant physical activity and participated in competitive sports than women who engaged in no or only moderate physical activity. In addition to the intensity and type of activity, factors such as age, childbirth, number of childbirths, and BMI may have played a role $[10,13,14]$.

In their research, Araujo et al. [15] divided the respondents into athletes and non-athletes, while Fozzati et al. [16] divided the group into women attending and not attending the gym. Both researchers reported a higher prevalence of urinary incontinence in the group of people undertaking physical activity $[15,16]$. Similarly, a study by Fernandes et al. showed a higher rate $(63 \%)$ of UI in 12- to 19-year-old amateur female soccer players compared to girls not participating in sports, among whom $26 \%$ experienced uncontrollable urinary discharge [17]. A meta-analysis of eight studies by Araújo et al. [15,16,18-23] revealed that the mean expressed prevalence of urinary incon- 
tinence in women undertaking physical activity was $36.1 \%$. Borin et al. [18] obtained the lowest prevalence of UI (12.5\%) of all studies analyzed, while the highest (76\%) was obtained by Araujo et al. [15]. Our study shows that in the group of women undertaking systematic physical activity, the problem was reported by $18.2 \%$ of respondents, and in $8 \%$ of respondents the problem occurred in the past. Larsen et al. [20] obtained similar results, where this problem affected $19.4 \%$ of the subjects.

It is evident that the prevalence rate of urinary incontinence varies widely, which may be due to the heterogeneity of the study populations and the use of different exclusion criteria by the researchers. Many researchers have also attempted to determine the prevalence of this problem in various sports disciplines. Multiple studies have shown that the risk of UI is not associated with all types of physical activity. It has been shown that physical activities requiring high physical effort accompanied by a significant amount of running and jumping are more likely to predispose to episodes of uncontrolled urinary discharge [24,25].

This is supported by our research, which shows that CrossFit and activities combining strength and endurance exercises were the forms of exercise that most influenced urinary incontinence - this problem was reported by $29.0 \%$ of women practising them. An approximate result (30\%) was obtained in the study by Poli de Araujo et al. [26], which included 551 women practising CrossFit at a high level; however, an inclusion criterion was the absence of childbirth and normal body weight, which was not considered in our study. Furthermore, most researchers limited their studies to only a few sports; for example, Nygaard et al. [27] divided the subjects into two groups: high load, which included athletes and gymnasts, and low load, which included swimmers. Among them were multiparous women, and the mean age in the one group was 46.2 years and in the other group was 42.4 years. Women in the first group were more likely to report episodes of UI (35.8\%) when compared to the second group (4.5\%) [27]. Another study [28], analyzing women involved in
12 different sports, found that urinary incontinence was more common in female hockey and volleyball players when compared to other sports. In contrast, Eliasson et al. [29] studied 35 female trampoline jumpers aged $12-22$ years and found that UI occurred in up to $80 \%$ of them, which may also confirm that episodes of urinary incontinence are more common in sports accompanied by a large volume of jumping [29]. More extensive research was conducted by Thyssen [30] in which UI in different areas of physical activity was as follows: gymnastics (56\%), ballet (43\%), aerobics (40\%), badminton (31\%), volleyball (30\%), athletics (25\%), handball (21\%) and basketball (17\%). When analyzing the studies of many researchers, it can be pointed out that runners most often report UI, women attending CrossFit classes, fitness centres, gyms, women practising trampoline sports, or team sports such as basketball and volleyball.

Based on the questionnaire, it is difficult to determine whether the uncontrolled urine discharges were due to stress urinary incontinence (SUI) or other types of UI. However, when asked under what circumstances urine leakage occurs, the vast majority of women reported experiencing leakage during exercise, coughing, sneezing, or laughing, which would indicate the SUI. Some cross-sectional studies have shown that urinary incontinence can be a barrier to physical activity, causing women to modify or stop exercising because of fear of leakage or odour [31,32]. In contrast, among the surveyed women, only $1 \%$ of them reported stopping exercising because of this issue, indicating that women do not let UI become a barrier to exercise and continue to enjoy the other positive health benefits of physical activity. However, continuing with such exercises can weaken the pelvic floor muscles and worsen symptoms in the long run. Interestingly, more than half of the women perceive their problem as minor (occasional), and urine leakage during training was admitted by $81.3 \%$ of the women reporting UI. Such contradiction may indicate using strategies such as urination before exercise or restricting fluid intake, which may mask UI symptoms, thereby reducing their frequency. 
In this study, despite the lack of statistical significance between variables related to physical activity and the prevalence of UI, a higher percentage of urinary incontinence was observed among women performing more than two trainings a week and a slightly higher percentage among those training for shorter periods (30 - 90 $\mathrm{min}$ ) than among those training for $2 \mathrm{~h}$ and longer. Women who have UI may choose a shorter workout, which would explain its reduced occurrence among those who spend $2 \mathrm{~h}$ or more on exercise. Similarly, research conducted by Haakstad et al. [33] found no change in the ratio between training experience and severity of incontinence among women attending fitness classes. A different result was obtained by Simeone et al. [23], where UI was correlated with prolonged training and frequent uncontrollable urine discharges. An interesting observation is that the intensity of training defined as a low, medium, and high also did not play any significant role in terms of the discussed problem, which is interesting because another study found a high correlation between urinary leakage symptoms and the intensity of physical activity [34]. However, this may be due to the fact that the study by Hagowska et al. [34] used the International Physical Activity Questionnaire (IPAQ) to estimate the metabolic equivalent of exercise intensity, rather than just the number of hours per day and days per week, which allowed for more accurate measurement. In contrast, Nygaard et al. [35] demonstrated that intense physical activity of more than 7.5 hours/ week slightly increased the likelihood of urinary incontinence in the long term.

The presented study differs from those of many researchers because of the heterogeneity of the study group, since it was deliberately decided to examine a group of physically active women, including a wide range of ages, childbirths, non-births, and varying body weights since together these factors could potentially account for the prevalence rate of urinary incontinence. Undoubtedly, age plays an important role in the aetiology of the presented issue and its prevalence increases with age [36]. This is probably related to the changes in the structure and function of pelvic floor muscles in older people, leading to their weakening [37]. Our study confirmed that impaired urinary control was more commonly reported by older women $(\mathrm{p}<0.05)$. Interestingly, women between the ages of 29 and 40 had the highest rates of UI. This may be because women over the age of 41 choose lower intensity exercise to reduce their risk of incontinence.

The effect of childbirth on the occurrence of urinary incontinence was reported, among others, by Thom et al. [38] and was also confirmed in our study $(\mathrm{p}<0.05)$. Furthermore, Yang et al. [37] found that while nearly half of nulliparous and parous women participating in CrossFit activities experience urine leakage during exercise, parous women are more likely to experience this when not exercising. This indicates that childbirth may contribute to the onset and severity of incontinence among women with physical activity.

However, there were no statistically significant differences associated with body weight and the prevalence of urinary incontinence. This may be due to the fact that most of the subjects were in the normal BMI range, and as reported in the literature $[39,40]$, a body mass index greater than $30 \mathrm{~kg} / \mathrm{m}^{2}$, a sign of obesity, is a factor that can contribute to the onset of UI problems as well as exacerbate the issue. Although the data are not statistically significant, it can be seen that the prevalence of incontinence increases with increasing BMI, which was also reported by Subak et al. [41], who also noticed this correlation. The mechanism by which obesity and weight gain contribute to or exacerbate urinary incontinence is thought to be related to a steady increase in intra-abdominal pressure, causing stretching as well as muscle and nerve weakening [42].

Our study also revealed statistically significant correlations $(\mathrm{p}<0.05)$ between women with higher education and other women regarding the prevalence of urinary incontinence. It would seem that women with higher education have a higher level of knowledge and show a proactive attitude towards the problems that affect them, which would indicate a lower extent of this issue 
in this group. However, the results of our study were the opposite - women with higher education were more likely to report these symptoms than women with primary and secondary education. This may be due to the fact that women, regardless of education, have a low level of knowledge about prevention and treatment of incontinence, or it can be assumed that women with higher education were older; and as previously proven, age is one of the factors contributing to incontinence, which would explain the higher prevalence in this group.

The second part of our research assessed the subjects' knowledge of prevention and treatment of UI and aimed to investigate whether women were using these strategies to protect and treat this pelvic floor dysfunction. The literature reports that pelvic floor muscle training is the cornerstone of prevention and conservative treatment of urinary incontinence [43]. The majority of participants are aware of this, as $70.1 \%$ of respondents provided this response. The respondents demonstrated even higher awareness in the study conducted by Zyznawska et al. [11], with 90\% indicating these exercises as prevention of urinary incontinence. Another important piece of information from our research is that $17.8 \%$ of women do not know any UI prevention methods. However, these data are more satisfactory compared to the results of the study by Chmiel et al. [10], whereas many as $84.5 \%$ of the respondents showed a lack of knowledge about the use of preventive methods. Although most women were able to identify preventive methods, almost half of the participants did not use them due to a lack of knowledge. Hence, based on the analysis, the respondents have a strong interest in the need to establish UI advisory services. Such results indicate that women want to avoid the problem of urinary incontinence, but they do not have enough knowledge about this issue. It is also worth mentioning that $70.8 \%$ of the women favour establishing such informative and educational programs by trainers, which would indicate that the coaches do not promote such activities among their trainees. Therefore, in light of the fact that urinary incontinence affects people who exercise more frequently than people who do not, pelvic floor muscle training (PFMT) should most definitely be included in the training program, and instructors should be adequately educated on this issue, as a recent study reported that the main reason why women do not use PMFT is because they do not have enough knowledge [44].

Later in the study, women were also asked to identify a specialist to whom a woman struggling with this problem should go. The largest number of participants selected a gynaecologist, while in the research conducted by Chmiel et al. [10], the largest number of women said that it should be a urologist, which was selected by our study only $11.7 \%$ of respondents. Interestingly, the general practitioner in both our study and Chmiel et al. [10] was not placed first, as this would seem to be the first step to initiate further specialist treatment. Moreover, $7.6 \%$ of respondents do not know which specialist a woman should see. Furthermore, in other studies [10], the participants $(16.7 \%)$ did not know to whom they should report this problem.

Furthermore, women's poor knowledge of urinary incontinence means that they often ignore the first symptoms and fail to undergo diagnosis and treatment. This may be related to the embarrassment of talking to a doctor about their problem or fear of surgical treatment. This result can be interpreted by the fact that women did not consider UI as a serious issue. This result can be explained by the fact that women did not consider urinary incontinence a serious issue. Another factor that may influence this is women's poor awareness of the various treatment options. However, it is satisfactory that the most frequently selected form of treatment was pelvic floor muscle training due to the high effectiveness of this method in treating the discussed problem [45]. Hence, in $42.2 \%$ of the respondents, the problem significantly decreased and in $33.3 \%$, the problem disappeared. The data suggests great possibilities of helping women struggling with urinary incontinence using physiotherapeutic interventions. The same conclusion was also reached by Zygmunt et al. 
[46], in where $53 \%$ of the participants reported a significant reduction in urinary discharge and $42 \%$ reported no discharge.

\section{Conclusion}

The presented results demonstrate the prevalence of UI among women undertaking systematic physical activity, which accounts for $18.2 \%$ of the participants and is significantly related to the practised form of physical activity. Treating women as a single group (with multiple risk factors) did not explain how physical activity alone may contribute to this pelvic floor dysfunction. However, it was noted that there is a higher prevalence among older women, have a higher BMI, have given birth, and these factors, along with sports participation, may contribute to incontinence.
Further clinical studies should be conducted to obtain more detailed and accurate results, including diagnostic procedures to analyze the prevalence of UI among athletes and physically active women. Further evaluation of variables such as training duration, number of workouts per week, length of a single workout per week, and intensity is necessary and the assessment of their impact on pelvic floor muscle dysfunction, including urinary incontinence, which should also be supplemented with additional diagnostic criteria (e.g., using the IPAQ to estimate the intensity of physical activity). Additionally, the lack of knowledge about the prevention and treatment of UI indicates the need to promote education among women in outpatient clinics, hospitals, and coaches of various sports disciplines or fitness instructors.

\section{References}

1. Adamiak A, Jankiewicz K. Epidemiologia nietrzymania moczu. [w:] Rechberger T. (red. nauk.). Nietrzymanie moczu i zaburzenia statyki dna miednicy $\mathrm{u}$ kobiet. Poznań: Termedia Wydawnictwo Medyczne; 2009: 19-25.

2. Radzymińska A. Ocena skuteczności ćwiczeń mięśni dna miednicy u kobiet z wysiłkowym nietrzymaniem moczu. Torun: Wydawnictwo Naukowe Uniwersytetu Mikołaja Kopernika; 2019.

3. Cantieni B. Tigerfeeling Trening mięśni dna miednicy dla niej i dla niego. Wrocław: Edra Urban \&Partner; 2017.

4. Strupińska E. Physiotherapy in urinary incontinence - exercise techniques and methodology. Przegl Urol. 2007;8(46):17-9.

5. Paczkowska A, Friebe Z, Koszla M. Combined treatment of mixed incontinence with electicalstimulation and biofeedback procedures. Przegl Urol. 2002;3(6):57-9.

6. Nygaard IE, Thompson FL, Svengalis SL, Albright JP. Urinary incontinence in elite nulliparous athletes. Obstet Gynecol. 1994;84(2):183-7.
7. Pertyński T, Stachowaik G. Menopauza jako czynnik ryzyka nietrzymania moczu u kobiet. [w:] Rechberger T, Jakowicki JA. (red. nauk.). Nietrzymanie moczu u kobiet. Patologia, diagnostyka, leczenie. Lublin: Biofolium; 2005: 95-105.

8. Friebe Z. Zachowawcze metody leczenia wysiłkowego nietrzymania moczu u kobiet - stan wiedzy na rok 2005. [w:] Rechberger T, Jakowicki JA. (red. nauk.). Nowe trendy w uroginekologii. Lublin: Wydawnictwo Instytut Zastosowań Techniki; 2005: 198-213.

9. Kaszuba KO. Nietrzymanie moczu u aktywnych fizycznie kobiet. Nieopublikowana praca magisterska pod kierunkiem Chomiuka T. Warszawa: WUM; 2020: 28-58.

10. Chmiel I, Biliński G, Witkoś J. Występowanie wysiłkowego nietrzymania moczu wśród sportsmenek. Koło Naukowe Katedry Fizjoterapii, Śląski Uniwersytet Medyczny w Katowicach 2012; 347-62.

11. Zyznawska J, Buksa M, Załęcka M, Królikowska A, Lipiński K. Level of awareness of selected university students on stress urinary incontinence in women. Health Prom Phys Act. 2019;3(8):29-37. 
12. Bø K, Nygaard IE. Is Physical Activity Good or Bad for the Female Pelvic Floor? A Narrative Review. Sports Med. 2020;50(3):471-84.

13. Chisholm L, Delpe S, Priest T, Reynolds WS. Physical Activity and Stress Incontinence in Women. Curr Bladder Dysfunct Rep. 2019;14(3):174-9.

14. McKenzie S, Watson T, Thompson J, Briffa K. Stress urinary incontinence is highly prevalent in recreationally active women attending gyms or exercise classes. Int Urogynecol J. 2016; 27:1175-84.

15. Araújo MP, Parmigiano TR, Negra LGD et al. Avaliação do assoalho pélvico de atletas: existe relação com a incontinência urinária?. Rev Bras Med Esporte. 2015; 21(6):442-6.

16. Fozzati C, Riccetto C, Herrmann V et al. Prevalence study of stress urinary incontinence in women who perform high-impact exercises. Int Urogynecol J. 2012; 23(1):1687-91.

17. Fernandes A, Fitz F, Silva A et al. Evaluation of the prevalence of urinary incontinence symptoms in adolescent female soccer players and their impact on quality of life. Occup Environ Med. 2014;71:59-60.

18. Borin LCMS, Nunes FR, Guirro ECOG. Assessment of pelvic floor muscle pressure in female athletes. PM\&R 2013;5(1):189-93.

19. Jácome C, Oliveira D, Marques A, Sá-Couto P. Prevalence and impact of urinary incontinence among female athletes. Int J Gynaecol Obstet. 2011;114(1):60-3.

20. Larsen IW, Yavorek TA. Pelvic organ prolapse and urinary incontinence in nulliparous women the United States Military Academy. Int Urogynecol J. 2006;17(1):208-10.

21. Patrizzi LJ, Viana DA, Silva LMA, Pegorari MS. Incontinência urinária em mulheres jovens praticantes de exercício físico. Rev Bras Ciênc Mov. 2014;22(3):105-10.

22. Poświata A, Socha T, Opara J. Prevalence of stress urinary incontinence in elite female endurance athletes. J Hum Kinet. 2014;44:91-6.

23. Simeone C, Moroni A, Pettenò A, et al. Occurrence rates and predictors of lower urinary tract symptoms and incontinence in female athletes. Urologia. 2010;77(2):139-46.
24. Harvey MA. Pelvic floor exercises during and after pregnancy: a systematic review of their role in preventing pelvic floor dysfunction. J Obstet Gynaecol Can. 2003;25(6):487-98.

25. Pietkiewicz A, Goluda M. Nietrzymanie moczu u kobiet - rola lekarza rodzinnego. Pol Med Rodz. 2000;2(2):131-4.

26. Poli de Araújo M, Brito LGO, Rossi F et al. Prevalence of Female Urinary Incontinence in Crossfit Practitioners and Associated Factors: An Internet Population-Based Survey. Female Pelvic Med Reconstr Surg. 2020; 2(26):97-100.

27. Nygaard I. Does Prolonged High-impact Activity Contribute to Later Urinary Incontinence? A Retrospective Cohort Study of Female Olympians, Obstet Gynecol. 1997,90(5):718-22.

28. Stadnicka G, Iwanowicz - Palus GJ. The etiology of stress urinary incontinence in terms of vaginal delivery Part I. Część I. Eur J Med Technol. 2014;4(9):8-15.

29. Eliasson K, Larsson T, Mattsson E. Prevalence of stress incontinence in nulliparous elite trampolinists. Scand J Med Sci Sports. 2002;12(2):106-10.

30. Thyssen HH, Clevin L, Olesen S, Lose G. Urinary Incontinence in Elite Female Athletes and Dancers, Int Urogynecol J. 2002,13(1):15-7.

31. Ghaderi F, Oskouei AE. Physiotherapy for women with stress urinary incontinence: a review article. J Phys Ther Sci. 2014;26(9):1493-9.

32. Purc D, Rasała A. Method of treating urinary incontinence. Eur J Med Technol. 2015;3(8):29-38.

33. Haakstad LAH, Gjestvang C, Lamerton T, Bø K. Urinary incontinence in a fitness club settin$\mathrm{g}$-is it a workout problem?. Int Urogynecol J. 2020;31(9):1795-802.

34. Hagovska M, Svihra J, Bukova A, Horbacz A, Svihrova $V$. The impact of physical activity measured by the International Physical Activity questionnaire on the prevalence of stress urinary incontinence in young women. Eur J Obstet Gynecol Reprod Biol. 2018;228:308-12.

35. Nygaard I, Shaw J, Egger MJ. Exploring the association between lifetime physical activity and pelvic floor disorders: study and design challenges. Contemp Clin Trials. 2012;33(4):819-27. 
36. Gołąbek T, Chłost P. Nietrzymanie moczu u kobiet i mężczyzn. Poznań: Termedia Wydawnictwo Medyczne; 2016.

37. Yang J, Cheng JW, Wagner H, et al. The effect of high impact crossfit exercises on stress urinary incontinence in physically active women. Neurourol Urodyn. 2019;38(2):749-56.

38. Thom DH, van den Eeden SK, Brown JS. Evaluation of parturition and other reproductive variables as risk factors for urinary incontinence in later life. Obstet Gynecol. 1997;90(6):983-9.

39. Ptak M, Mosiejczuk H, Szylińska A, Rotter I. The infl uence of grade 1 stress urinary incontinence on the physical activity of women depending on nutritional status as defi ned by the Body Mass Index. Pomeranian J Life Sci. 2016;62(1):67-71.

40. Sosnowski M. Fizjoterapia w uroginekologii. W: Fizjoterapia

41. w wybranych dziedzinach medycyny, red. nauk. Olszewski J. Warszawa: Wydawnictwo Lekarskie PZWL; 2011: 261-88.

42. Subak LL, Johnson C, Whitcomb E, Boban D, Saxton J, Brown JS. Does weight loss improve incontinence in moderately obese women? Int Urogynecol J Pelvic Floor Dysfunct. 2002;13(1):40-3.
43. Waetjen LE, Liao S, Johnson WO et al. Factors associated with prevalent and incident urinary incontinence in a cohort of midlife women: a longitudinal analysis of data: study of women's health across the nation. Am J Epidemiol. 2007;165(3):309-18.

44. Bø K. Pelvic floor muscle strength and response to pelvic floor muscle training for stress urinary incontinence. Neurourol Urodyn. 2003;22(7):654-8.

45. Stephen K, van Woerden H, MacRury S. Assessing prevalence of urinary incontinence in Scottish fitness instructors and experience of teaching pelvic floor muscle exercises: an online survey. J Public Health (Oxf). 2019;41(1):44-50.

46. Dumoulin C, Cacciari LP, Hay-Smith EJC. Pelvic floor muscle training versus no treatment, or inactive control treatments, for urinary incontinence in women. Cochrane Database Syst Rev. 2018;10(10):CD005654.

47. Zygmunt R, Kozioł S, Hładki W, Golec J. The influence of physiotherapy on incontinence in women. Ostry Dyżur 2017; 3(10):77-83. 